\section{Spine Wars: The Lessons of YODA}

\author{
Jens Chapman ${ }^{1}$ \\ ${ }^{1}$ Department of Orthopaedics and Sports Medicine, University of \\ Washington School of Medicine, Seattle, Washington, United States
}

Evid Based Spine Care J 2013;4:67.

Feel the Force

-Master Yoda

With this editorial message, I would like to encourage as many of our global interdisciplinary readers of $\sim 10,000$-and moreover, PubMed readers-to pull the referenced articles below, and after privately reading them, discuss them in your journal clubs, grand rounds, and scientific meetings. The implications of the readings relate to how we conduct our evidence evaluations as presented in published medical literature. Without wanting to sound overly dramatic, I do believe that we may have witnessed with these publications a cataclysmic change in the way prospective clinical science and trials in general-specifically, in spine-will be conducted and reported in the future.

The topic of bone morphogenic protein has surely been a most contentious subject. Questions of patient safety (cancer risk, heterotopic bone formation, neuritis, dysphagia, and others) have been raised and the actual likelihood of these possible complications have been previously discussed here in $E B S J^{1}$ and in many other publications. It is not an exaggeration to speak of a "war" waged in the arena of academic publications and the court of public opinions through public media. To form your own opinion, I ask you to study the articles of Simmonds et al, ${ }^{2}$ and Fu et $\mathrm{al}^{3}{ }^{3}$ which are closely related to the much-anticipated results of the Yale University Open Data Access study (YODA $)^{4}$ published in the June issue of the Annals of Medicine.

The gist of my editorial message is, however, not focused on the merits of bone morphogenic protein, but rather on the bigger picture of how to conduct large-scale clinical research going forward. One of the main conclusions of the authors and commentators was that open data reporting for major clinical trials would have been preferable to avoid concerns about selective reporting of potentially important clinical findings., As shown by the open publication of this data in full cooperation with its industrial sponsor (Medtronic, Inc., Minneapolis, United States), the YODA publications ${ }^{2,3}$ resulted in a general call to conduct all future clinical trials with full data transpar-

ency and opportunity for data sharing among qualified investigators. This would signal a major departure from the traditional proprietary- and secrecy-cloaked nature, not only of industrysponsored research, but also any form of funded, clinical trialstype research, while also requiring a review of applicable patient privacy laws, as some patient identifiers will invariably become more apparent.

However we look at it, the forces YODA has unleashed may be truly transformational; it will be interesting to see how in the future, possibly contentious device-, technique-, or medication-based trials will be structured in light of this very noteworthy publication series. As always, I welcome your opinions in this interesting turn of events in the field of evidence-based medicine.

\title{
References
}

1 Devine JG, Dettori JR, France JC, Brodt E, McGuire RA. The use of rhBMP in spine surgery: is there a cancer risk? Evid Based Spine Care J 2012;3(2):35-41

2 Simmonds MC, Brown JV, Heirs MK, et al. Safety and effectiveness of recombinant human bone morphogenetic protein-2 for spinal fusion: a meta-analysis of individual-participant data. Ann Intern Med 2013;158(12):877-889

3 Fu R, Selph S, McDonagh M, et al. Effectiveness and harms of recombinant human bone morphogenetic protein-2 in spine fusion: a systematic review and meta-analysis. Ann Intern Med 2013;158(12):890-902

4 Krumholz HM, Ross JS, Gross CP, et al. A historic moment for open science: the Yale University Open Data Access project and medtronic. Ann Intern Med 2013;158(12):910-911

5 Kuntz RE. The changing structure of industry-sponsored clinical research: pioneering data sharing and transparency. Ann Intern Med 2013;158(12):914-915

6 Resnick D, Bozic KJ. Meta-analysis of trials of recombinant human bone morphogenetic protein-2: what should spine surgeons and their patients do with this information? Ann Intern Med 2013; 158(12):912-913

(c) 2013 Georg Thieme Verlag KG Stuttgart · New York
DOI http://dx.doi.org/ $10.1055 / \mathrm{s}-0033-1360453$. ISSN 1663-7976. 